ENTREPRENEURSHIP AND SUSTAINABILITY ISSUES

ISSN 2345-0282 (online) http://jssidoi.org/jesi/

2020 Volume 8 Number 2 (December)

http://doi.org/10.9770/jesi.2020.8.2(35)

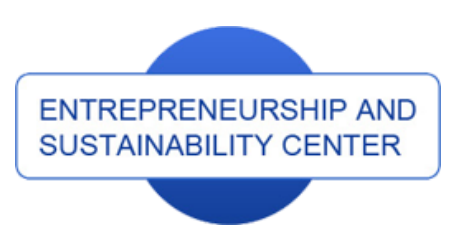

Publisher

$\underline{\text { http://jssidoi.org/esc/home }}$
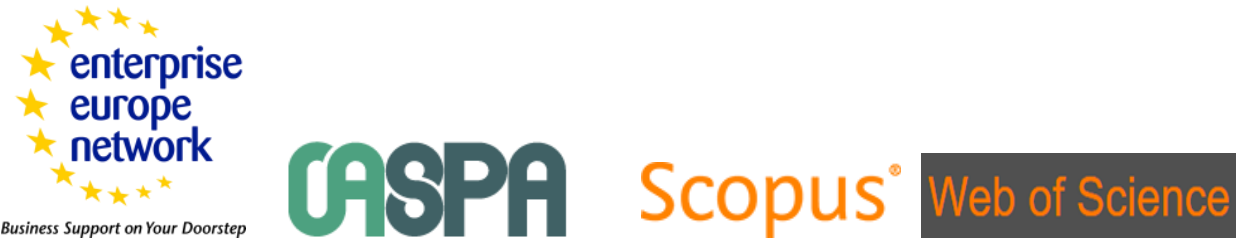

I) Clarivate

Analytics

\title{
INVESTMENT INCENTIVES AS INSTRUMENT OF MOTIVATION OF FIRMS AND ECONOMIC STABILIZATION"
}

\author{
Petr Musil ${ }^{1}$, Veronika Hedija ${ }^{2}$ \\ 1,2 Department of Economic Studies, College of Polytechnics Jihlava, Tolstého 16, 58601 Jihlava, Czech Republic \\ E-mails: ${ }^{1}$ Petr.Musil@vspj.cz $;{ }^{2}$ Veronika.Hedija@vspj.cz
}

Received 15 May 2020; accepted 30 August 2020; published 30 December 2020

\begin{abstract}
Investment incentives are mostly presented as an efficient tool of economic policy to eliminate negative impacts of economic cycle and also as the tools of motivation of firms to generation of investment. The aim of the paper is to verify the relationship between investment incentives and business cycle in the Czech Republic. There is used the data of CzechInvest, Czech Statistical Office and Organisation for Economic Cooperation and Development. To verify the link between the investment incentives and the business cycle, the Pearson correlation coefficient and Spearman correlation coefficient was used. There has been identified moderate positive relationship between the volume of the state support and the growth of the gross domestic product in constant prices. The link between investment incentives and output gap was not statistically significant. The study brings new insights on the field of investment incentives as an instrument of stabilization of economy. Investment incentives are important in terms of stimulating the investment activity of firms. Findings of the study answer the question of whether the government behaves responsibly in the area of investment incentives. The findings show that the policy of investment incentives does not respond flexibly to the current needs of the Czech economy.
\end{abstract}

Keywords: investment incentives; business cycle; Czech Republic; economic stability; gross domestic product

Reference to this paper should be made as follows: Musil, P., Hedija, V. 2020. Investment incentives as instrument of motivation of firms and economic stabilization. Entrepreneurship and Sustainability Issues, 8(2), 578-589. http://doi.org/10.9770/jesi.2020.8.2(35)

JEL Classifications: E22, E32

\footnotetext{
* This research was supported by the project, which has been funded by College of Polytechnics Jihlava from Grant Number 1170/4/199
} 


\section{ENTREPRENEURSHIP AND SUSTAINABILITY ISSUES}

ISSN 2345-0282 (online) http://jssidoi.org/jesi/

2020 Volume 8 Number 2 (December)

http://doi.org/10.9770/jesi.2020.8.2(35)

Make your research more visible, join the Twitter account of ENTREPRENEURSHIP AND SUSTAINABILITY ISSUES: @Entrepr69728810

\section{Introduction}

An investment incentive can be understood as a measurable advantage granted by a government to a particular firm, firm or group of firms in order to induce them to behave. By using investment incentives, the state seeks to encourage an increase in the volume of investments in its territory (Srholec 2004). The investment incentive can be provided by the state in practically two ways. Direct financial support or indirect relief from state requirements to companies or individuals. Direct support may be represented by a subsidy for the purchase of machinery, land, infrastructure, equipment or other means of production. On the other hand, reliefs take the form of a reduction or total remission of taxes, duties, social security contributions, as well as exemptions from the obligations imposed on entities by the legal order.

The objectives of investment incentives may vary. Sometimes they are advocated to support less developed regions affected by the structural crisis, high unemployment and low living standards. At other times, economic policy makers expect investment incentives to contribute to the establishment of macroeconomic equilibrium, particularly with regard to the business cycle. If economic activity in the country is declining, unemployment tends to grow, then there should be an incentive that motivates the investor to allocate his capital to the economy that offers the incentive. Investment incentives began to be used more extensively in the Czech Republic in 1998, when the domestic economy underwent its first major recession after most of the measures for economic transformation were implemented (Žídek 2006). This was a direct consequence of the 1997 currency crisis, which spilled over into the real economy in the coming months.

Promoting investment as an effective remedy for economic downturn is entirely in line with the economic theory based on the teachings of John Maynard Keynes and his followers. Keynesians rely on the interconnection of the multiplier and accelerator principles to drive aggregate demand and thus help restore economic performance to its potential (Dornbusch, Fischer 2013). On the basis of this logic, massive support for investment by the state should come just at a time of decline in gross domestic product, and on the contrary, in times of rapid economic growth, the state should save on investment incentives. Accordingly, the volume of supported investments should also evolve, which should be countercyclical.

The aim of the paper is therefore to assess whether investment incentives have been treated in this way in the past 20 years. In particular, to assess the relationship between investment incentives in the Czech Republic and the evolution of the output of the economy and to assess whether the investment incentives were used to act countercyclically.

The findings of the study help us to answer the question of whether the government behaves responsibly in the area of investment incentives and whether their setting does not contribute to the deepening cyclical fluctuations of the economy.

\section{Literature review and theory development}

Investment incentives can be seen as one of the possible instruments for promoting economic growth, but also as an instrument for stabilizing the economy.

According to traditional macroeconomic theory, investment is one of the factors determining the level of equilibrium output of the economy and is also an important factor of economic growth. The increase of 


\section{ENTREPRENEURSHIP AND SUSTAINABILITY ISSUES}

ISSN 2345-0282 (online) http://jssidoi.org/jesi/

2020 Volume 8 Number 2 (December)

http://doi.org/10.9770/jesi.2020.8.2(35)

Make your research more visible, join the Twitter account of ENTREPRENEURSHIP AND SUSTAINABILITY ISSUES: @Entrepr69728810

investment in the country leads to an increase in aggregate demand and thus also to an increase in the real output of the economy. The accumulation of investment contributes to the growth of the country's production potential and thus to the growth of potential output (Dornbusch, Fischer 2013).

The impact of investment on the performance of the economy is examined by a number of empirical studies. These confirm the positive impact of investment on economic growth in most cases (Khan, Reinhart 1990; Anderson 1990; Bal et al. 2016). The empirical studies also confirm that the private investment appears to have a higher pro-growth effect compared to government investment (Khan, Reinhart 1990). Investment incentives can be seen as one of the possible instruments for promoting economic growth, but also as an instrument for stabilizing the economy.

According to traditional macroeconomic theory, investment is one of the factors determining the level of equilibrium output of the economy and is also a factor of economic growth. The increase in investment in the country leads to an increase in aggregate demand and thus also to an increase in the real output of the economy. The increase in investment as such contributes to the growth of the country's production potential and thus to the growth of potential output (Dornbusch, Fischer 2013).

The impact of investment on the performance of the economy is examined by a number of domestic and foreign studies. These mostly confirm the positive impact of investment on economic growth (Khan, Reinhart 1990; Anderson 1990; Bal et al. 2016). Private investment also appears to have a higher pro-growth effect compared to government investment (Khan, Reinhart 1990). The positive effect of investment on economic growth can also be found also in the Czech Republic. Křístková (2012) examines the impact of investment in science and research on economic growth in the Czech Republic. It concludes that these investments contribute to economic growth, but their impact is lower than that of investments in capital goods.

Some studies focus on examining the relationship between investment and the business cycle. According to Levy Yeyati et al. (2007), the economic cycle can affect investment through multiple factors. In the period of expansion (when the output is above the level of potential product) companies have higher incomes and profits and these motivate them to invest both in the home country and abroad. This effect who is referred as the 'income effect' by the authors, will lead to the so-called pro-cyclical behaviour of domestic investment and foreign direct investment abroad. On the other hand, so-called "substitution effect" will result in a situation where the economy is in the phase of expansion. It means that the firms will prefer domestic investment over foreign direct investment abroad. The reason is the expected higher return on domestic investment, as the expected value of investment during the period of expansion is growing. And also lower risk of domestic investment compared with foreign investment, especially those in developing countries. (Levy Yeyati et al. 2007)

The vast majority of empirical studies confirm of the fact that not only domestic investment but also foreign direct investment directed abroad are in line with the economic cycle. They tend to grow as economies are in a phase of expansion and decline in times of recession (for example, Levy Yeyati et al. 2007; Rodriguez, Bustillo 2015).

There are also number of studies examining the impact of investment incentives on economic development and selected macroeconomic indicators. The results of these studies are not uniform. Some studies confirm the positive impact of investment incentives on development of economy (mainly on productivity and employment) (for example Harris, Trainor 2005; Schalk, Untiedt 2000). Other papers do not identify statistically significant effect and these dominated (for example Daly et al. 1993; Bernini, Pellegrini 2011; Yanikkaya, Karaboga 2017). 


\section{ENTREPRENEURSHIP AND SUSTAINABILITY ISSUES}

ISSN 2345-0282 (online) http://jssidoi.org/jesi/

2020 Volume 8 Number 2 (December)

http://doi.org/10.9770/jesi.2020.8.2(35)

Make your research more visible, join the Twitter account of ENTREPRENEURSHIP AND SUSTAINABILITY ISSUES: @Entrepr69728810

However, the system of investment incentives varies among individual countries and also the effect of investment incentives policy on development of the county may be country specific. The results for the Czech Republic are not uniform too. Some studies identified the positive effect of investment incentives. For example, Adamek and Rybkova (2015) examined the effect of investment incentives on development of regional unemployment in the Czech Republic. They concluded that investment incentives can promoting employment and development of regions and have positive and statistically significant influence on regional employment. Pícl (2013) examined the system of investment incentives in the Czech Republic and assess their real impacts on the Czech economy. Based on the findings of own survey, he concludes that most of the supported investments would be realized without state financial support and the investment incentives have not significant impact on the level of investment. Bolcha and Zemplinerová (2012) examined the effect of investment incentives on firm real investments and concluded that the effectiveness of investment incentives is very low. The extra investment generated due to invement incentives was at most $26 \%$ of contracted amounts.

Some papers mention the negative circumstances of investment incentives, such as distorting the market, changing employment patterns, raising wage levels in poor regions, and thus dragging labour from local employers, we find quite a lot. One analysis is the study by Schwarz et al. (2007) prepared for the Ministry of Industry and Trade of the Czech Republic. The authors conclude that investment incentives merely substitute an insufficient level of key decision-making factors for investors: political stability, law enforcement, low taxes, functioning infrastructure and the quality of the workforce. Investment incentives are thus only at best the second best alternative if the government is unable to ensure the required level of these factors.

Although the real effect of investment incentives on economic output and economic growth is not clear, it is an important and frequently used instrument of economic policy.

\section{Data and methods}

The article aims to evaluate the relationship between the amount of investment incentives and the development of economic output. The data needed to assess the relationship are drawn from three sources. The first is CzechInvest, then the Czech Statistical Office (CSU) and the Organization for Economic Cooperation and Development (OECD).

The data on the amount of supported investments and the level of support (percentage of support of the realized investment) are taken from data provided by CzechInvest (2018). It is a contributory organization subordinated to the Ministry of Industry and Trade of the Czech Republic, whose main objective is to support entrepreneurship and investment and which also provides information on the amount of the granted investment incentives.

The data on the amount of supported investments and the aid intensity in the period 1998-2017 were used. The nominal values of the indicators and the values expressed in constant prices (2015 prices) are used for the calculations in order to adjust for the effect of changes in the price level. Consumer price index, which is derived from data provided by the Czech Statistical Office (2018), is used for conversion to constant prices. The output of the economy and its development is evaluated using the growth rate of real gross domestic product and the estimate of the output gap in 1998-2017. These data are drawn from data provided by the Czech Statistical Office (2018a) and data provided by the OECD (2018).

Pearson's correlation coefficient is used to assess the relationship between the amount of investment incentives and the output of the economy, respectively output gap. It is complemented by the Spearman's rank correlation 
Make your research more visible, join the Twitter account of ENTREPRENEURSHIP AND SUSTAINABILITY ISSUES: @Entrepr69728810

coefficient (de Vaus 2002). Spearman's rank correlation coefficient makes it possible to identify the relationship even in the case of existing non-linearity. The limits recommended by de Vaus (2002) for the evaluation of dependence in the social sciences are used to assess the strength of the relationship between the quantities under study. The calculations were carried out in the STATA program.

The Pearson's correlation coefficient is calculated using the following formula:

$$
r=\frac{\sum_{i=1}^{n}\left(x_{i}-\bar{x}\right)\left(y_{i}-\bar{y}\right)}{\sqrt{\sum_{i=1}^{n}\left(x_{i}-\bar{x}\right)^{2} \sum_{i=1}^{n}\left(y_{i}-\bar{y}\right)^{2}}} .
$$

Where $x_{i}$ and $y_{i}$ are the quantities between which we investigate the relationship, $\bar{x}$ and $\bar{y}$ are the mean values of $x_{i}$ and $y_{i}$.

The Spearman' correlation coefficient is calculated as follows:

$r=1-\frac{6 \sum\left(R x_{i}-R y_{i}\right)^{2}}{\mathrm{n}\left(\mathrm{n}^{2}-1\right)}$

Where $R x_{i}$ and $R y_{i}$ - represent the order of values $x_{i}$ and $y_{i .}$.

\section{Results}

All investment activity was very difficult immediately after the fall of the communist regime in November 1989. Forty years of a centrally planned economy took its toll. Capital was regarded in official circles as a term that was in stark contrast to the ideology of socialism. Accordingly, capital was also treated at the level of state or national enterprises. The result was its total shortage in the early 1990s (Žídek 2006).

It was possible to use foreign capital, but its flow was strictly limited until the mid-1990s. Foreign investment came to the Czech Republic to a very small extent. According to the Czech National Bank (2018), only 19 billion Czech crowns in foreign direct investment came to us in 1993. In 1996 it was almost 68 billion and a breakthrough occurred in 1998, when the Czech Republic for the first time flowed in direct foreign investment over 100 billion Czech crowns.

In the same year, the Investment Incentives Act came into force, on the basis of which domestic and foreign investors could apply for state aid. CzechInvest, which was established at the end of 1992 and is established by the Ministry of Industry and Trade, was in charge of the administration and assessment of applications. While in 1993 CzechInvest managed to make two investments worth 361 million Czech crowns, five years later (and probably due to the launch of investment incentives) it was already 41 investments worth 40 billion Czech crowns. Companies such as Johnson Controls (USA), Panasonic AVC (Japan) or Hella-Behr (Germany) came to the Czech Republic. In the coming years, the inflow of investment into the Czech Republic naturally intensified as the domestic economy became more and more stable and the risk of a reversal of the post-November development 
Make your research more visible, join the Twitter account of ENTREPRENEURSHIP AND SUSTAINABILITY ISSUES: @Entrepr69728810

decreased. The accession to the European Union in May 2004 became a definite signal that the Czech Republic is suitable for foreign investments.

Between 1998 and 2017, according to CzechInvest (2018), 1127 investment projects benefited from some form of state support, of which 53 percent were from abroad. Over 15 percent are in Germany, less than 5 percent in Japan or the Netherlands, while other countries occupy lower percentages. The total volume of investments supported by CzechInvest reached 864.3 billion Czech crowns in the period under review. The state supported them with the amount of almost 290 billion Czech crowns. Thus, the average aid intensity was 33.3 percent. In other words, one Czech crown was added by the state to every two Czech crowns invested.

Interestingly, the aid intensity has been decreasing in the long term. It reached its maximum (50 percent) only in 1999 and has been steadily declining ever since. It was the lowest (not counting the first year of existence of investment incentives) in 2016, at twenty percent.

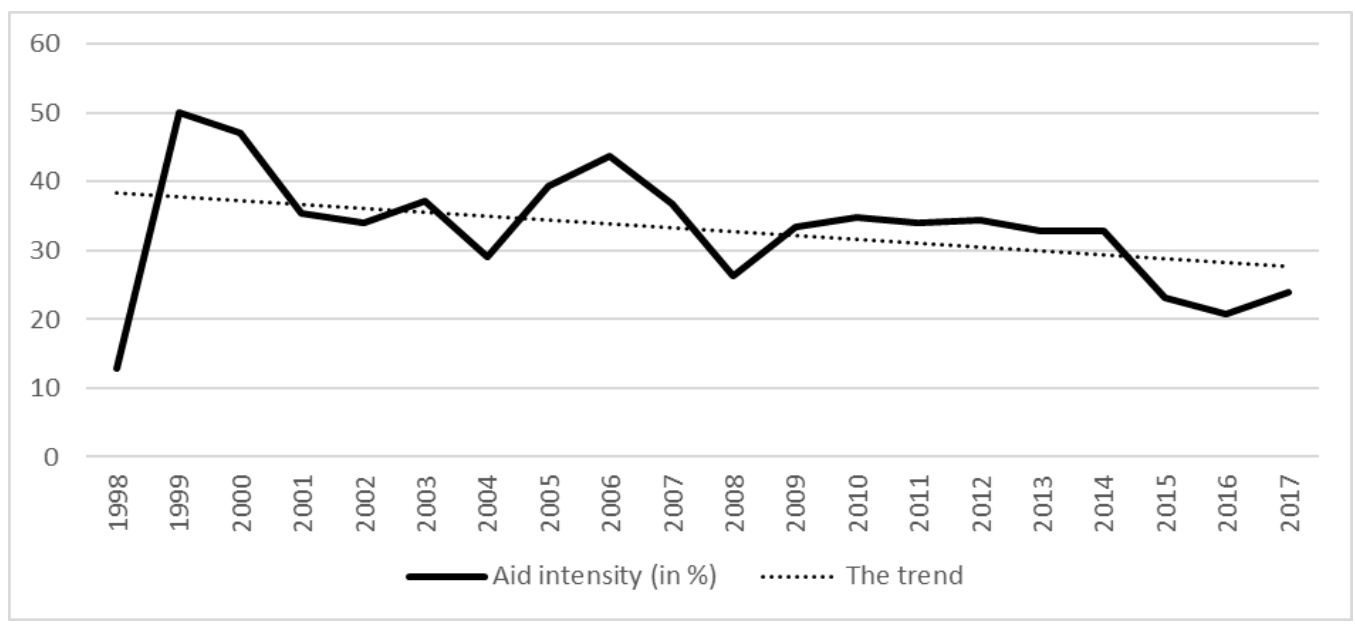

Figure 1. Aid intensity of investments supported by CzechInvest 1998 - 2017 (in \%)

Source: CzechInvest (2018), own calculations

As already mentioned, it can be seen from Figure 1 that the aid intensity of investments declines over time. One explanation may be the fact that in the beginning of the examined period the (mainly) foreign investment was still under relatively high political risk in the Czech Republic. And the investors perceived this very sensitively. Therefore, the state compensated them precisely through relatively generous support.

This is also reflected in the rapidly increasing volume of supported investments in 2000 and 2001. The situation is illustrated in Figure 2, where we can see the development of the volume of supported investments in the period 1998-2017. In 2000, supported investments increased by 168 percent year on year, and grew by almost 27 percent in 2001. 
Make your research more visible, join the Twitter account of ENTREPRENEURSHIP AND SUSTAINABILITY ISSUES: @Entrepr69728810

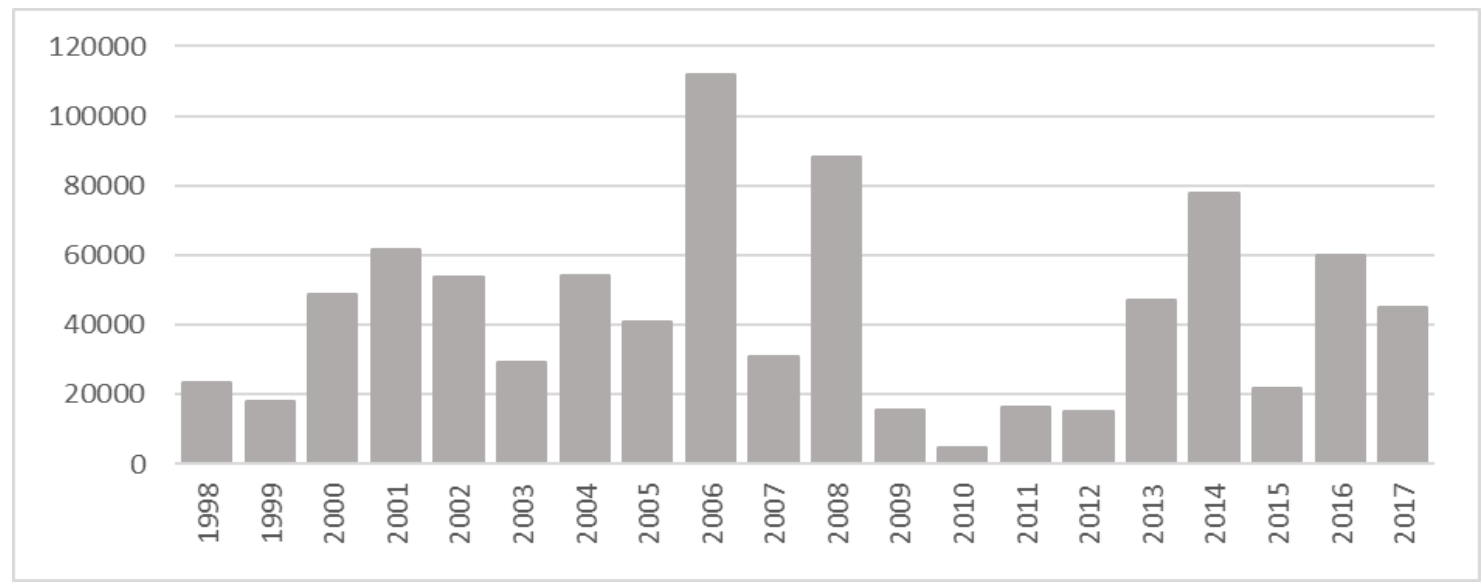

Figure 2. Volume of supported investments by CzechInvest in 1998 - 2017 (in millions of CZK) Source: CzechInvest (2018)

As already mentioned, investment incentives are seen as a highly effective tool for eliminating the negative impacts of the business cycle. Thus, the volume of supported investments could be expected to grow as the economy goes through recession and, on the contrary, will dampen if economic growth shows a solid pace. The volume of supported investments should therefore develop counter-cyclically.

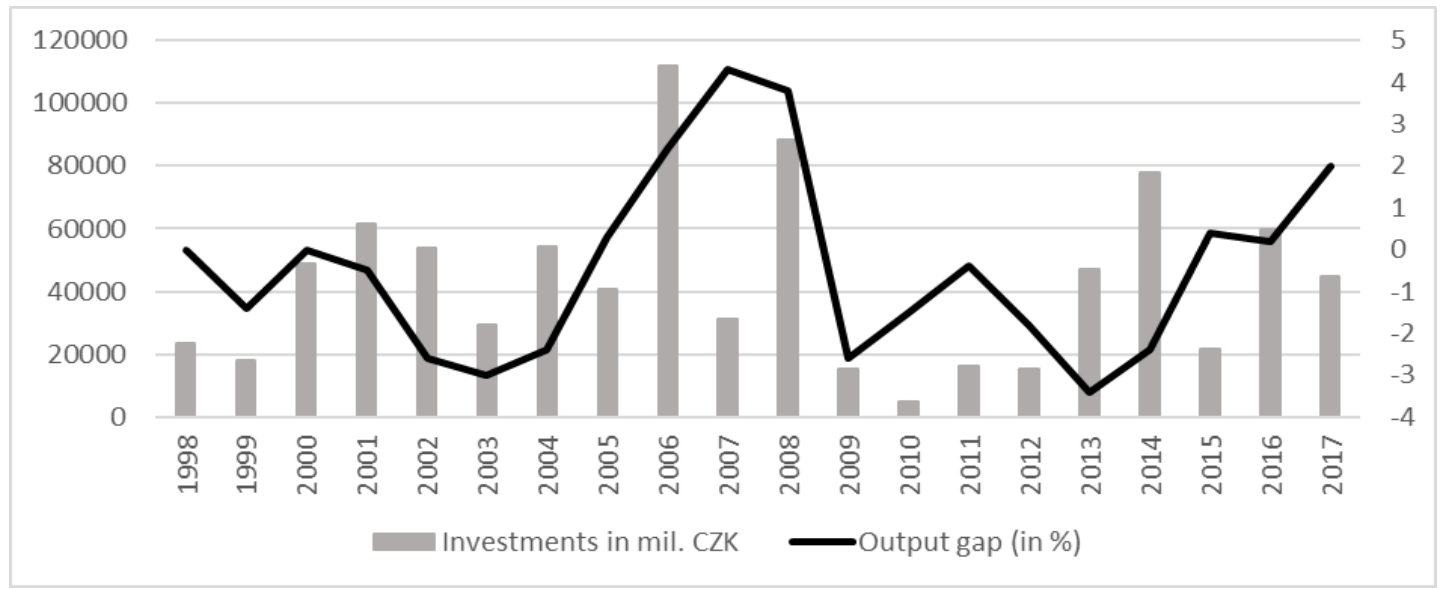

Figure 3. Volume of supported investments by CzechInvest and output gap in 1998 - 2017

(in millions of CZK, output gap in \% - right axis)

Source: CzechInvest (2018), Czech Statistical Office (2018)

Figure 3 illustrates the evolution of the volume of supported investment and the growth rate of real gross domestic product over the period 1998-2017. The data show that in the period of growth in the performance of the Czech economy, the volume of supported investments increased and in the period of decline the volume of investment incentives decreased. This shows rather the pro-cyclical use of investment incentives. However, this hard one needs to be further examined for several reasons. 


\section{ENTREPRENEURSHIP AND SUSTAINABILITY ISSUES}

ISSN 2345-0282 (online) http://jssidoi.org/jesi/

2020 Volume 8 Number 2 (December)

http://doi.org/10.9770/jesi.2020.8.2(35)

Make your research more visible, join the Twitter account of ENTREPRENEURSHIP AND SUSTAINABILITY ISSUES: @Entrepr69728810

The growth rate of real gross domestic product does not faithfully reflect the business cycle. If the growth rate of real gross domestic product increase, this does not necessarily mean that the economy is reaching potential output. This may reflect the growth of the potential product as such. In other words, real gross domestic product growth is not adjusted for changes in potential output as such. The phase of the business cycle is best illustrated by the output gap, which is estimated as the difference between actual and potential product and is reported as a percentage of potential product.

Further distortion may result from the use of the absolute amount of supported investments. As the price level increases, so does the cost of the investments made and the absolute amounts that investors ask for. The real volume of investments does not need to change. It is therefore appropriate to take this into account in the analysis and to adjust the investment for the effect of the price level change. In assessing the counter-cyclicality of the investment incentives policy implemented, it is also necessary to distinguish between the total volume of supported investments and the actual amount of support, where the percentage of government funds in the supported investment may change over time and as shown in Figure 1 over the examined period.

The Pearson's correlation coefficient (equation 1) is used to assess the relationship between investment incentives and economic performance and the Spearman's order correlation coefficient (equation2) to capture the possible non-linearity of the relationship.

To take into account all of the above mentioned factors, we use alternative indicators for the amount of investment incentives and the output of the economy in our analysis. Investment incentives are used in the form of the total amount of supported investments in millions of CZK (investment incentives) and also as the amount of support that captures the actual volume of government funds directed at investment incentives in CZK million (supported volume). These indicators are examined in nominal and also absolute terms (in 2015 prices) to adjust it for the effect of price level changes. The output of the economy is measured by real gross domestic product growth rate and by output gap.

The results are shown in Table 1 and Table 2. Table 1 deals with the nominal value of investment incentives and the amount of aid, in Table 2 these indicators are adjusted for the price level and enter into the calculation, as already mentioned, in 2015 prices.

Table 1. Pearson's and Spearman's correlation coefficients (investment incentives in current prices)

\begin{tabular}{|c|c|c|}
\hline \multicolumn{3}{|c|}{ Pearson's correlation coefficient } \\
\hline & Growth rate of real GDP (in \%) & Output gap (in \%) \\
\hline Investment incentives & $0.4284^{*}$ & 0.3372 \\
\hline Support volume & $0.4769^{* *}$ & 0.2775 \\
\hline $\mathrm{N}$ & 20 & 20 \\
\hline \multicolumn{3}{|c|}{ Spearman's correlation coefficient } \\
\hline Investment incentives & Growth rate of real GDP (in \%) & Output gap (in \%) \\
\hline Support volume & $0.4400^{*}$ & 0.2303 \\
\hline $\mathrm{N}$ & $0.4325^{*}$ & 0.1310 \\
\hline
\end{tabular}

Note: *** statistically significant at the $1 \%$ significance level, ** statistically significant at the 5\% significance level, * statistically significant at the $10 \%$ significance level. Source: own calculations in STATA 


\section{ENTREPRENEURSHIP AND SUSTAINABILITY ISSUES}

ISSN 2345-0282 (online) http://jssidoi.org/jesi/

2020 Volume 8 Number 2 (December)

http://doi.org/10.9770/jesi.2020.8.2(35)

Make your research more visible, join the Twitter account of ENTREPRENEURSHIP AND SUSTAINABILITY ISSUES: @Entrepr69728810

Table 2. Pearson's and Spearman's correlation coefficients (investment incentives in constant prices of 2015)

\begin{tabular}{|c|c|c|}
\hline \multicolumn{2}{|c|}{ Pearson's correlation coefficient } \\
\hline & Growth rate of real GDP (in \%) & Output gap (in \%) \\
\hline $\begin{array}{c}\text { Investment incentives (in price } \\
2015 \text { ) }\end{array}$ & $0.4554^{* *}$ & 0.3228 \\
\hline Support volume (in price 2015) & $0.4912^{* *}$ & 0.2627 \\
\hline $\mathrm{N}$ & 20 & 20 \\
\hline \multicolumn{2}{|c|}{ Spearman's correlation coefficient } \\
\hline \multicolumn{2}{|c|}{ Growth rate of real GDP (in \%) } & Output gap (in \%) \\
\hline $\begin{array}{c}\text { Investment incentives (in price } \\
\text { 2015) }\end{array}$ & $0.4453^{* *}$ & 0.1837 \\
\hline Support volume (in price 2015) & $0.4370^{*}$ & 0.0640 \\
\hline $\mathrm{N}$ & 20 & 20 \\
\hline
\end{tabular}

Note: *** statistically significant at the $1 \%$ significance level, ** statistically significant at the 5\% significance level, * statistically significant at the $10 \%$ significance level.

Source: Own calculations in STATA

A statistically significant relationship between the level of investment incentives and the growth rate of real gross domestic product was identified in the examined period 1997-2017. In the years with a higher real gross domestic product growth rate, the amount of investment incentives also increased in the country. Depending on the level of Pearson and Spearman correlation coefficients, the strength of the identified relationship can be described as medium. When comparing the results in Tables 1 and 2, it can be stated that the identified relationship is stronger in the case of investments adjusted for the effect of price level changes (Table 2).

The conclusions are also similar for the relationship between the supported volume and the growth rate of real gross domestic product. Conversely, the relationship between the level of investment incentives and the output gap did not prove to be significant. Moreover, the value of correlation coefficients indicates the existence of a weak or insignificant relationship. Investment incentive policy is thus not used counter-cyclically.

\section{Discussion}

The findings of this study are not very surprising and show that the investment incentive policy does not respond flexibly to the current needs of the economy in terms of trying to stimulate the economy in times of recession and lower performance and, conversely, to subdue the economy at risk of overheating. Rather, the system appears to be pro-cyclical, with higher real output growth rates and positive corporate expectations motivating firms to invest more, and, if the system permits, they also benefit from investment incentives. As real gross domestic product increases, the amount of total investment incentives and the amount of support also increase.

Bolcha and Zemplinerová (2012) and Pícl (2013) pointed to the low effectiveness of investment incentives in relation to the volume of extra investment genderated due to investment incentives in the Czech Republic. Our findings show that the system si also rather pro-cyclical. From this point of view, the Czech investment incenstives system does not appear effective. Bolcha and Zemplinerová (2012) expect that the abolition of the investment incentives would have only the low effect on the total volume of investment, and it would bring savings in the form of state budget expenditures decline.

The issues of investment incentives impact on the state budget and gross domestic product growth are very interesting and important and deserve the deeper analysis in the Czech Republic. Harms and Meon (2018) show 
ENTREPRENEURSHIP AND SUSTAINABILITY ISSUES

ISSN 2345-0282 (online) http://jssidoi.org/jesi/

2020 Volume 8 Number 2 (December)

http://doi.org/10.9770/jesi.2020.8.2(35)

Make your research more visible, join the Twitter account of ENTREPRENEURSHIP AND SUSTAINABILITY ISSUES: @Entrepr69728810

that the different types of foreign direct investments can have a different effect on economic growth and conclude that greenfield invesments have a stronger impact on growth than mergers and acquisitions. The detailed analysis of the impacts of investment incentives on economic growth in the Czech Republic with a focus on various types of realized investments will be the subject of the further research.

\section{Conclusions}

Investment incentives are important in terms of stimulating the investment activity of firms. The article was devoted to the issue of investment incentives and to assessing whether investment incentives were used in the Czech Republic in the period 1998-2017 so that they could contribute to smoothing the economic cycle.

The principles of the system of investment incentives are briefly summarized in the paper. At the same time, it was stated what amount of investments the Czech state has supported through its CzechInvest agency over the past twenty years. Although the system was set up in such a way that entities regardless of their country of origin could benefit from it, initially it was mainly used by foreign investors. Only in recent years did Czech companies "level the score". The ratio of the number of Czech and foreign investors who received the incentive is virtually one to one in two decades.

The aid intensity has been decreasing since the start of the investment incentive scheme. It reached the highest, i.e. 50 percent, in 1999, in recent years it has been between 20 and 25 percent of the total volume of supported investments. Investment incentives can also be used as a tool for economic stabilization. In order the investment incentives could act counter-cyclically, it would have to be true that they are increasing at a time when the economy is below potential output and, on the contrary, declining when the output of the economy is above potential output.

Using the Pearson correlation coefficient and the Spearman order correlation coefficient, the relationship between investment incentives (represented by the total volume of supported investments by actual aid amount) and the performance of the economy (represented by real GDP growth rate and output gap) was tested. A statistically significant directly proportional moderate relationship between the level of investment incentives and real gross domestic product growth rate was identified. In other words, investment incentives, both in terms of total volume and actual aid intensity, grew at the same time as the growth rate of gross domestic product increased. Conversely, in a situation where the rate of gross domestic product growth declined (or was negative), investment incentives declined too. They could thus to some extent act pro-cyclically. On the other hand, the relationship between the level of investment incentives and the output gap, which more accurately reflects the evolution of the economic cycle than the actual growth rate of the real product, proved to be statistically insignificant.

So we can say that the government did not show any tendency to increase investment incentives at a time when the economy was below the potential output and vice versa. The main driver of investment incentives seems to be the interest of companies and investors, which logically grows at a time when the economy is reaching higher growth rates of its performance. 


\section{ENTREPRENEURSHIP AND SUSTAINABILITY ISSUES}

ISSN 2345-0282 (online) http://jssidoi.org/jesi/

2020 Volume 8 Number 2 (December)

http://doi.org/10.9770/jesi.2020.8.2(35)

Make your research more visible, join the Twitter account of ENTREPRENEURSHIP AND SUSTAINABILITY ISSUES: @Entrepr69728810

\section{References}

Adámek, E. \& Rybková, L. (2015). Influence of Investment Incentives on Development of Regional Unemployment in the Czech Republic. European Journal of Business Science and Technology, 1(1), 5-14. https://doi.org/10.11118/ejobsat.v1i1.33

Anderson, D. (1990). Investment and Economic Growth. World Development, 18, 1057-1079.

Bal, P. D., Devi, P. D. \& Subhasish. B. (2016). The Effects of Capital Formation on Economic Growth in India: Evidence from ARDLbound Testing Approach. Global Business Review, 17(6), 1388-1400. https://doi.org/10.1177/0972150916660403

Bernini, C. \& Pellegrini, G. (2011). How Are Growth and Productivity in Private Firms Affected by Public Subsidy? Evidence from a Regional Policy. Regional Science and Urban Economics, 41(3), 253-265. https://doi.org/10.1016/j.regsciurbeco.2011.01.005

Bolcha, P. \& Zemplinerová, A. (2012). The Effect of Investment Incentives on Investment in the Czech Republic. Politická ekonomie, 60(1), 81-100. https://doi.org/10.18267/j.polek.833

Czech National Bank (2018). Data primých zahraničnich investic (Direct Investment Incentives Data). Retrieved March 16, 2020, from https://www.cnb.cz/cs/statistika/platebni_bilance_stat/publikace_pb/pzi/

Czech Statistical Office (2018). Index spotrebitelských cen - inflace - časové řady (Consumer Price Index - Time series). Retrieved March 16, 2020, from https://www.czso.cz/csu/czso/isc cr.

Czech Statistical Office (2018a). Hlavni makroekonomické ukazatele (Main Macroeconomics Indicators). Retrieved March 16, 2020, from https://www.czso.cz/csu/czso/hmu_cr.

CzechInvest (2018). Udělené investični pobidky $k$ 31.9.2018 (Investment incentives in 31/9/2018). Retrieved March 16, 2020, from https://www.czechinvest.org/cz/Sluzby-pro-investory/Investicni-pobidky.

Daly, M., Gorman, I., Lenjosek, G., Macnevin, A. \& Phiriyapreunt, W. (1993). The Impact of Regional Investment Incentives on Employment and Productivity - Some Canadian Evidence. Regional Science and Urban Economics, 23(4), 559-575.

De Vaus, D. (2002). Analyzing Social Science Data. 50 Key Problems in Data Analysis. London: Sage Publications.

Dornbusch, R. \& Fischer, S. (2013). Macroeconomics. New York: McGraw-Hill.

Harms, P. \& Méon, P. G. (2018). Good and useless FDI: The growth effects of greenfield investment and mergers and acquisitions. Review of International Economics, 26(1), 37-59. https://doi.org/10.1111/roie.12302

Harris, R. \& Trainor, M. (2005). Capital Subsidies and Their Impact on Total Factor Productivity: Firm-Level Evidence from Northern Ireland. Journal of Regional Science, 45(1), 49-74. https://doi.org/10.1111/j.0022-4146.2005.00364.X

Khan, M. S. \& Reinhart, C. M. (1990). Private Investment and Economic Growth in Developing Countries. World Development, 18(1), 1927.

Kř́stková, Z. (2012). Impact of R\&D Investment on Economic Growth of the Czech Republic - A Recursively Dynamic CGE Approach. Prague Economic Papers, 2012(4), 412-433. https://doi.org/10.18267/j.pep.432

Levy Yeyati, E., Panizza, U. \& Stein, E. (2007). The Cyclical Nature of North-South FDI Flows. Journal of International Money and Finance, 26(1), 104-130.

Ministry of Industry and Trade (2018). Zákon č. 72/2000 Sb. o investičních pobídkách ve znění pozdějších předpisů (Act No. $72 / 2000$ Coll., on Investment Incentives). Retrieved May 12, 2020, from https://www.mpo.cz/assets/cz/podnikani/dotace-a-podporapodnikani/investicni-pobidky-a-prumyslove-zony/investicni-pobidky/2016/12/Zakon-o-investicnich-pobidkach_84_2015.pdf.

OECD (2018). Economic Outlook November 2018. Retrieved November 16, 2019, from http://www.oecd.org/eco/outlook/economicoutlook/ 


\section{ENTREPRENEURSHIP AND SUSTAINABILITY ISSUES}

ISSN 2345-0282 (online) http://jssidoi.org/jesi/

2020 Volume 8 Number 2 (December)

http://doi.org/10.9770/jesi.2020.8.2(35)

Make your research more visible, join the Twitter account of ENTREPRENEURSHIP AND SUSTAINABILITY ISSUES: @Entrepr69728810

Pícl, M. (2013). Impact of incentive driven investment in the Czech Republic. Business and IT, 2013(2), 43-64.

Rodriguez, C. \& Bustillo, R. (2015). Foreign Direct Investment and the Business Cycle: New Insights after the Great Recession. Prague Economic Papers, 2015(2), 136-153. https://doi.org/10.18267/j.pep.505

Schalk, H. J. \& Untiedt, G. (2000). Regional Investment Incentives in Germany: Impacts on Factor Demand and Growth. The Annals of Regional Science, 34(2), 173-195. https://doi.org/10.1007/s001689900008

Schwarz, J. et al. (2007). Analýza investičních pobídek v České republice (Invesmtent Incentives Analysis). Praha: Ministerstvo průmyslu a obchodu. Retrieved May 9, 2020, from https://www.mpo.cz/assets/dokumenty/32013/35445/388865/priloha001.pdf

Srholec, M. (2004). Př́mé zahraniční investice v České republice - Teorie a praxe v mezinárodním srovnávání (Foreign Direct Investment in the Czech Republic - Theory and Practice in International comparison). Praha: Linde.

Yanikkaya, H. \& Karaboga, H. (2017). The Effectiveness of Investment Incentives in the Turkish Manufacturing Industry. Prague Economic Papers, 26(6), 744-760. https://doi.org/10.18267/j.pep.641

Žídek, L. (2006). Transformace české ekonomiky 1989 - 2004 (Transformation of the Czech Economy 1989-2004). Praha: C. H. Beck.

\section{Acknowledgements}

This research was supported by the project entitled "Possibilities of interconnection of multi-criterial decision-making methods and simulation models in solving real decision-making problems", which has been funded by College of Polytechnics Jihlava from Grant Number 1170/4/199.

Petr MUSIL is the Assistant professor at the Department of Economic Studies of the College of Polytechnics Jihlava. Research interests: economic policy; wage inequality; economic growth and sustainability; renewable energy sources policy.

ORCID ID: orcid.org/0000-0002-8164-2181

Veronika HEDIJA is the Assistant professor at the Department of Economic Studies of the College of Polytechnics Jihlava. Research interests: firm performance; sustainability; women in leadership; gender wage differences.

ORCID ID: orcid.org/0000-0002-5353-1505

Copyright (C) 2020 by author(s) and VsI Entrepreneurship and Sustainability Center This work is licensed under the Creative Commons Attribution International License (CC BY). http://creativecommons.org/licenses/by/4.0/

cC) (i) Open Access 